\author{
ACTA UNIVERSITA T IS LODZIENS IS \\ FOLIA OECONOMICA 6(326) 2016 \\ http://dx.doi.org/10.18778/0208-6018.326.07
}

\author{
Ewa Staszewska*
}

\title{
NOWE INSTRUMENTY RYNKU PRACY NA RZECZ AKTYWIZACJI ZAWODOWEJ GRUP DEFAWORYZOWANYCH NA RYNKU PRACY W ŚWIETLE USTAWY O PROMOCJI ZATRUDNIENIA I INSTYTUCJACH RYNKU PRACY
}

\begin{abstract}
Streszczenie. Przedmiotem artykułu są instrumenty rynku pracy, których celem jest aktywizacja zawodowa grup defaworyzowanych na rynku pracy. Analizie poddane zostały nowe instrumenty rynku pracy wprowadzone do ustawy o promocji zatrudnienia i instytucjach rynku pracy z 2004 r. na skutek gruntownej nowelizacji z maja 2014 r. Nowe instrumenty rynku pracy mają za zadanie zwiększyć elastyczność działania urzędów pracy poprzez lepsze ich dostosowanie do potrzeb konkretnego bezrobotnego i pracodawcy. Zasadniczym celem nowych instrumentów jest pomoc w wejściu na rynek pracy i utrzymanie się na nim osobom młodym (do 30. roku życia) oraz osobom starszym (powyżej 50. roku życia), a także ułatwienie łączenia pracy zawodowej z obowiązkami rodzinnymi związanymi z wychowywaniem dzieci czy opieką nad osobą zależną. W odniesieniu do bezrobotnych do 30. roku życia wprowadzono instrumenty mające motywować te osoby do samodzielnego podejmowania działań zmierzających do zatrudnienia (m.in. wprowadzono system bonów). W celu aktywizacji zawodowej osób bezrobotnych powyżej 50. roku życia stworzona została możliwość ubiegania się przez pracodawców o dofinansowanie do wynagrodzenia za zatrudnienie skierowanego bezrobotnego, który ukończył 50. rok życia. Wprowadzone zostały także nowe instrumenty mające na celu umożliwienie godzenia obowiązków rodzinnych $\mathrm{z}$ zawodowymi tj. grant na telepracę oraz świadczenie aktywizacyjne.

Slowa kluczowe: grupy defaworyzowane na rynku pracy, instrumenty rynku pracy, system bonów, grant na telepracę, zatrudnienie subsydiowane.
\end{abstract}

JEL: E24, I38, J14, J21, J23, J24, J29, J61, J64, J68, J69, K31

\section{WPROWADZENIE}

Stopień zagrożenia zjawiskiem bezrobocia nie jest jednakowy dla całej zbiorowości społecznej. Pewne grupy osób są nieproporcjonalnie bardziej zagrożone pozostawaniem poza zatrudnieniem - można stwierdzić, że są szczególnie „predestynowane" do znalezienia się bez pracy. Istnieją bowiem znaczne różnice pomiędzy bezrobociem poszczególnych grup społecznych, co w konsekwencji oznacza, że z punktu widzenia społeczno-ekonomicznego ludzie wobec bezrobocia nie są

* Uniwersytet Łódzki, Wydział Prawa i Administracji, Katedra Prawa Pracy, estaszewska @ wpia.uni.lodz.pl 
równi (Góral 2002a: 193; Staszewska 2010: 233). Szanse na uzyskanie zatrudnienia są skorelowane nie tylko z kondycją gospodarki, która w okresie dobrej koniunktury pozwala na utrzymanie optymalnego poziomu zatrudnienia oraz sprzyja tworzeniu nowych miejsc pracy, ale także w dużej mierze z cechami społeczno-demograficznymi bezrobotnych takimi jak wiek, płeć, wykształcenie, stan rodzinny etc. (Szylko-Skoczny 2004: 225; Góral 2002b: 33). Wskazane zmienne nie są neutralne z punktu widzenia bezrobocia, co potwierdzają dane statystyczne dotyczące skali i struktury bezrobocia. Wynika z nich, że bezrobocie dotyka przede wszystkim ludzi młodych. W końcu I kwartału 2016 r. najliczniejszą grupą wśród bezrobotnych były osoby w wieku 25-34 lata, stanowiąc 28,1\% ogólnej liczby bezrobotnych. Osoby w wieku do 24 lat stanowiły 14,6\%. Odsetek zarejestrowanych w wieku 35-44 lata wyniósł $21,6 \%, 45-54$ lat - 18,1\%, a powyżej 55 lat $-17,6 \%$. Większość bezrobotnych rejestrujących się w urzędach pracy to osoby o stosunkowo niskim poziomie wykształcenia. Dwie najliczniejsze grupy wśród bezrobotnych to osoby posiadające wykształcenie zasadnicze zawodowe oraz gimnazjalne, podstawowe i niepełne podstawowe (odpowiednio $27,1 \%$ i $28 \%$ w ogólnej liczbie bezrobotnych, co oznacza, że obie te populacje łącznie stanowiły aż 55,1\% ogólnej liczby bezrobotnych). Biorąc pod uwagę konieczność łączenia ról zawodowych z obowiązkami rodzinnymi, należy wskazać, że 16,4\% ogółu bezrobotnych posiada co najmniej jedno dziecko w wieku do 6. roku życia (Główny Urząd Statystyczny 2016).

Wymienione powyżej przykładowe zmienne istotnie wpływają na stopień zagrożenia bezrobociem, co powoduje, iż niezbędne jest przystosowanie regulacji prawnych do różnorodności zagrożeń tym zjawiskiem. W niniejszym opracowaniu przedstawione zostały nowe instrumenty rynku pracy wprowadzone do ustawodawstwa z zakresu bezrobocia w wyniku gruntownej nowelizacji z 2014 r., których celem jest aktywizacja zawodowa grup defaworyzowanych na rynku pracy. W artykule podjęto także próbę oceny przyjętych przez ustawodawcę rozwiązań na rzecz grup szczególnego ryzyka, opierając się m.in. na analizie danych statystycznych dotyczących liczby osób bezrobotnych, które rozpoczęly aktywizację w ramach nowych form wsparcia.

\section{GRUPY DEFAWORYZOWANE NA RYNKU PRACY}

Szczególne zagrożenie bezrobociem niektórych grup społecznych wymaga wzmożonej i bardziej ukierunkowanej pomocy w celu poprawy ich szans na znalezienie trwałego zatrudnienia, a także zapobieżenia wykluczeniu tych grup z rynku pracy (Szylko-Skoczny 2004: 225). Polski ustawodawca, konstruując prawne instrumentarium walki z bezrobociem, coraz silniej dostrzega zróżnicowaną sytuację na rynku pracy poszczególnych grup osób pozostających poza 
zatrudnieniem, choć należy zauważyć, że pierwsze regulacje prawne dotyczące problematyki bezrobocia cechował raczej uniformizm rozwiązań (Ustawa o zatrudnieniu... 1989; Ustawa o zatrudnieniu i bezrobociu... 1991). Było to z pewnością wynikiem braku doświadczenia w normowaniu zjawiska bezrobocia, które w postaci właściwej dla gospodarki wolnorynkowej nie występowało przed rozpoczęciem transformacji ustrojowej. Ponadto zróżnicowana struktura populacji bezrobotnych ujawniła się dopiero po pewnym czasie wraz z pogłębiającym się procesem restrukturyzacji gospodarki (Góral 2002a: 198).

Obowiązująca ustawa o promocji zatrudnienia i instytucjach rynku pracy z dnia 20 kwietnia 2004 r. (Ustawa o promocji... 2004) ${ }^{1}$ już w pierwotnej wersji w art. 49 zawierała katalog „osób będących w szczególnej sytuacji na rynku pracy". W pierwszych latach obowiązywania przedmiotowej regulacji do osób, które miały być traktowane priorytetowo ze względu na swój szczególnie niekorzystny status na rynku pracy zaliczane były osoby bezrobotne do 25 . roku życia, bezrobotni długotrwale, bezrobotni powyżej 50. roku życia, bezrobotni bez kwalifikacji zawodowych, bez doświadczenia zawodowego lub wykształcenia średniego, bezrobotni samotnie wychowujący co najmniej jedno dziecko do 18 . roku życia, bezrobotni którzy po odbyciu kary pozbawienia wolności nie podjęli zatrudnienia oraz bezrobotni niepełnosprawni (należy zaznaczyć, że katalog ten był wielokrotnie zmieniany). Osoby bezrobotne, które zostały zaliczone do grup ryzyka na rynku pracy, mogły liczyć na szereg instrumentów przeciwdziałania bezrobociu zarezerwowanych wyłącznie dla nich (były to m.in. prace interwencyjne, roboty publiczne, staż).

Na skutek ostatniej gruntownej nowelizacji ustawy o promocji zatrudnienia i instytucjach rynku pracy (Ustawa o zmianie... 2014) zmodyfikowano katalog grup ryzyka oraz wprowadzono nowe nieznane dotąd instrumenty rynku pracy adresowane do konkretnych grup bezrobotnych. Biorąc pod uwagę dostępne statystyki oraz aktualną sytuację na rynku pracy, do osób będących w szczególnej sytuacji na rynku pracy zostały zakwalifikowane osoby bezrobotne do 30. roku życia (30,5\% wśród wszystkich bezrobotnych), bezrobotni długotrwale $(55,7 \%$ wśród wszystkich bezrobotnych), bezrobotni powyżej 50. roku życia $(28,6 \%$ wśród wszystkich bezrobotnych), bezrobotni korzystający ze świadczeń z pomocy społecznej ( $2 \%$ wśród wszystkich bezrobotnych), bezrobotni posiadający co najmniej jedno dziecko do 6 roku życia (16,4\% wśród wszystkich bezrobotnych), bezrobotni posiadający co najmniej jedno dziecko niepełnosprawne do 18. roku życia $(0,2 \%$ wśród wszystkich bezrobotnych) oraz bezrobotni niepełnosprawni $(6,3 \%$ wśród wszystkich bezrobotnych) ${ }^{2}$. W obowiązującym stanie prawnym ustawodawca odszedł od generalnej zasady, iż wskazane powyżej, silnie zakorzenione

\footnotetext{
${ }^{1}$ Dalej jako u.p.z.

${ }^{2}$ Dane statystyczne dotyczą końca I kwartału 2016 r.
} 
w ustawodawstwie instrumenty rynku pracy, takie jak prace interwencyjne, roboty publiczne czy staż adresowane są tylko do bezrobotnych w szczególnej sytuacji na rynku pracy. Instrumenty te zaczęto stosować w sposób bardziej elastyczny wobec bezrobotnych, uwzględniając wyniki profilowania w celu optymalnego dostosowania oferowanej formy pomocy do potrzeb konkretnej osoby. W zamian za to wprowadzone zostały zupełnie nowe instrumenty rynku pracy na rzecz aktywizacji zawodowej grup defaworyzowanych na rynku pracy.

Do grup wymagających szczególnego wsparcia zostały zaliczone przede wszystkim dwie kategorie osób bezrobotnych wyodrębnione ze względu na wiek: osoby bezrobotne do 30. roku życia oraz osoby bezrobotne powyżej 50. roku życia. Ponadto szczególną troską objęte zostały osoby bezrobotne powracające na rynek pracy po przerwie związanej z wychowywaniem dziecka lub sprawowaniem opieki nad osobą zależną.

\section{INSTRUMENTY RYNKU PRACY DLA OSÓB BEZROBOTNYCH DO 30. ROKU ŻYCIA}

Sytuacja osób młodych na rynku pracy jest niekorzystna. Świadczą o tym wskazane we wstępie dane statystyczne, z których jednoznacznie wynika, że w populacji bezrobotnych grupa ta jest nadreprezentowana. Problem bezrobocia ludzi młodych, zwłaszcza tych, którzy po opuszczeniu systemu szkolnego usiłują wejść na rynek pracy, jest ogromnym wyzwaniem dla polityki zatrudnienia. Mówiąc o trudnej sytuacji na rynku pracy wśród ludzi młodych, należy mieć na uwadze sytuację demograficzną oraz niedoskonały z punktu widzenia potrzeb gospodarki rynkowej system edukacyjny (Góral 2006: 106). Powodem nierównowagi pomiędzy rynkiem pracy a ofertą szkolnictwa jest niedostosowanie strukturalne. Dramatycznie powiększają się rozbieżności pomiędzy ofertą szkół a zapotrzebowaniem rynku (Tomaszewski 2011: 19). Należy także wspomnieć o sferze mentalnej przedstawicieli młodego pokolenia, którzy często prezentują jednocześnie postawę pasywną i roszczeniową.

Ustawodawca zdecydował się na wprowadzenie trzech nowych instrumentów rynku pracy przeznaczonych dla młodych bezrobotnych do 30. roku życia. W pierwszej kolejności należy zwrócić uwagę na system bonów, które mogą być przyznawane na wniosek młodego bezrobotnego. Drugim nowym instrumentem wsparcia osób bezrobotnych do 30. roku życia jest refundacja kosztów składek na ubezpieczenia społeczne dla pracodawców, którzy zatrudniają osobę z tej grupy, o ile bezrobotny podejmuje pracę po raz pierwszy w życiu. Nowym rozwiązaniem jest również czasowe wyłączenie obowiązku opłacania składek na Fundusz Pracy za skierowanych zatrudnionych bezrobotnych, którzy nie ukończyli 30. roku życia. 


\subsection{System bonów}

Na system bonów składają się cztery rodzaje bonów: szkoleniowy, stażowy, zatrudnieniowy oraz bon na zasiedlenie. Wszystkie mają charakter uznaniowy i mogą zostać przyznane na wniosek osoby bezrobotnej do 30. roku życia. Pozytywna decyzja w sprawie przyznania bonu stanowi zobowiązanie powiatowego urzędu pracy do pokrycia określonych kosztów związanych z podjęciem szkolenia, stażu, zatrudnienia czy też zmianą miejsca zamieszkania na skutek podjęcia zatrudnienia. Wprowadzenie systemu bonów adresowanych do bezrobotnych do 30. roku życia ma za zadanie motywować te osoby do samodzielnego podejmowania działań zmierzających do zatrudnienia. Innowacyjność tego instrumentu polega na pobudzaniu i podtrzymywaniu aktywności młodej osoby w procesie poszukiwania zatrudnienia. Jednocześnie urzędy pracy odeszły od dotychczas stosowanej praktyki, zgodnie z którą to one były instytucjami zapewniającymi określone formy wsparcia. Bony w znacznej mierze oddają inicjatywę bezrobotnemu przy zapewnieniu niezbędnej kontroli wynikającej z dbałości o celowość wydatkowania środków (Ministerstwo Pracy 2014b: 4).

Tabela 1. Rodzaje bonów przewidzianych dla osób bezrobotnych do 30. roku życia

\begin{tabular}{|c|c|c|c|c|}
\hline $\begin{array}{c}\text { Kategoria } \\
\text { bonu }\end{array}$ & Cel bonu & $\begin{array}{l}\text { Forma prawna } \\
\text { współpracy }\end{array}$ & $\begin{array}{l}\text { Korzyści dla } \\
\text { młodego } \\
\text { bezrobotnego }\end{array}$ & $\begin{array}{l}\text { Korzyści dla } \\
\text { pracodawcy }\end{array}$ \\
\hline \begin{tabular}{|l|} 
Bon \\
szkoleniowy
\end{tabular} & \begin{tabular}{|l|} 
Gwarancja skie- \\
rowania bezro- \\
botnego do 30. \\
roku życia na \\
wskazane przez \\
niego szkolenie \\
oraz opłacenie \\
kosztów, które \\
zostaną poniesio- \\
ne w związku \\
z podjęciem \\
szkolenia.
\end{tabular} & \begin{tabular}{|l|} 
Skierowanie na \\
szkolenie przez \\
powiatowy \\
urząd pracy.
\end{tabular} & $\begin{array}{l}\text { Uzyskanie, uzupeł- } \\
\text { nienie lub doskona- } \\
\text { lenie umiejętności } \\
\text { i kwalifikacji zawo- } \\
\text { dowych potrzeb- } \\
\text { nych do wykony- } \\
\text { wania pracy, co } \\
\text { zwiększa szanse na } \\
\text { podjęcie zatrudnie- } \\
\text { nia. Młody bezro- } \\
\text { botny podejmuje } \\
\text { decyzję co do wy- } \\
\text { boru szkolenia. } \\
\end{array}$ & $\begin{array}{l}\text { Pozyskanie przeszkolo- } \\
\text { nego pracownika. }\end{array}$ \\
\hline $\begin{array}{l}\text { Bon } \\
\text { stażowy }\end{array}$ & $\begin{array}{l}\text { Gwarancja skie- } \\
\text { rowania bezro- } \\
\text { botnego do } 30 . \\
\text { roku życia do } \\
\text { odbycia stażu } \\
\text { u pracodawcy } \\
\text { wskazanego przez } \\
\text { bezrobotnego na } \\
\text { okres } 6 \text { miesięcy, } \\
\text { o ile pracodawca } \\
\end{array}$ & \begin{tabular}{|l|} 
Przez okres \\
pierwszych 6 \\
miesięcy bez- \\
robotny odby- \\
wa staż, a przez \\
kolejnych 6 \\
miesięcy jest \\
zatrudniany \\
przez praco- \\
dawcę, \\
\end{tabular} & $\begin{array}{l}\text { Przez } 6 \text { miesięcy } \\
\text { młody bezrobotny } \\
\text { nabywa umiejętno- } \\
\text { ści praktyczne do } \\
\text { wykonywania pra- } \\
\text { cy, a następnie na } \\
\text { okres kolejnych } 6 \\
\text { miesięcy nawiązuje } \\
\text { stosunek pracy } \\
\text { z pracodawcą, } \\
\end{array}$ & $\begin{array}{l}\text { Przez okres pierwszych } \\
6 \text { miesięcy pracodawca } \\
\text { nie ponosi konsekwencji } \\
\text { finansowych związa- } \\
\text { nych z przyjęciem sta- } \\
\text { żysty. } \\
\text { Dochodzi do minimali- } \\
\text { zowania ryzyka osobo- } \\
\text { wego pracodawcy. } \\
\text { Pracodawca, który } \\
\end{array}$ \\
\hline
\end{tabular}


Tab. 1 (cd.)

\begin{tabular}{|c|c|c|c|c|}
\hline 1 & 2 & 3 & 4 & 5 \\
\hline $\begin{array}{l}\text { Bon } \\
\text { stażowy }\end{array}$ & $\begin{array}{l}\text { zobowiąże się do } \\
\text { zatrudnienia } \\
\text { bezrobotnego po } \\
\text { zakończeniu } \\
\text { stażu przez okres } \\
6 \text { miesięcy. }\end{array}$ & $\begin{array}{l}\text { u którego odbył } \\
\text { staż. }\end{array}$ & $\begin{array}{l}\text { u którego odbył } \\
\text { staż. Młody bezro- } \\
\text { botny podejmuje } \\
\text { decyzję co do } \\
\text { wyboru pracodaw- } \\
\text { cy. }\end{array}$ & $\begin{array}{l}\text { zatrudnia młodego bez- } \\
\text { robotnego przez } 6 \text { mie- } \\
\text { sięcy po zakończeniu } \\
\text { stażu ma prawo do pre- } \\
\text { mii. Pracodawca pozy- } \\
\text { skuje pracownika } \\
\text { o pożądanych przez } \\
\text { siebie umiejętnościach, } \\
\text { które ten nabył w trakcie } \\
\text { odbywania stażu. }\end{array}$ \\
\hline $\begin{array}{l}\text { Bon zatrud- } \\
\text { nieniowy }\end{array}$ & $\begin{array}{l}\text { Gwarancja refun- } \\
\text { dacji części } \\
\text { kosztów wyna- } \\
\text { grodzenia } \\
\text { i składek na } \\
\text { ubezpieczenia } \\
\text { społeczne } \\
\text { w związku } \\
\text { z zatrudnieniem } \\
\text { bezrobotnego do } \\
\text { 30. roku życia, } \\
\text { któremu } \\
\text { powiatowy urząd } \\
\text { pracy przyznał } \\
\text { bon. }\end{array}$ & $\begin{array}{l}\text { Umowa o pracę } \\
\text { obejmująca } \\
\text { okres } 18 \text { mie- } \\
\text { sięcy. }\end{array}$ & $\begin{array}{l}\text { Młody bezrobotny } \\
\text { ma gwarancję } \\
\text { zatrudnienia przez } \\
\text { okres } 18 \text { miesięcy } \\
\text { u wybranego przez } \\
\text { siebie pracodawcy. }\end{array}$ & $\begin{array}{l}\text { Refundacja części kosz- } \\
\text { tów wynagrodzenia } \\
\text { i składek na ubezpiecze- } \\
\text { nia społeczne przez } \\
\text { okres } 12 \text { miesięcy } \\
\text { w wysokości zasiłku dla } \\
\text { bezrobotnych. }\end{array}$ \\
\hline $\begin{array}{l}\text { Bon na } \\
\text { zasiedlenie }\end{array}$ & $\begin{array}{l}\text { Może być przy- } \\
\text { znany w związku } \\
\text { z podjęciem } \\
\text { przez bezrobot- } \\
\text { nego do 30. roku } \\
\text { życia zatrudnie- } \\
\text { nia lub innej } \\
\text { pracy zarobkowej } \\
\text { lub działalności } \\
\text { gospodarczej } \\
\text { poza miejscem } \\
\text { dotychczasowego } \\
\text { zamieszkania. }\end{array}$ & $\begin{array}{l}\text { Umowa } \\
\text { w sprawie } \\
\text { przyznania } \\
\text { środków } \\
\text { z Funduszu } \\
\text { Pracy. }\end{array}$ & $\begin{array}{l}\text { Uzyskanie środków } \\
\text { z Funduszu Pracy } \\
\text { w wysokości mak- } \\
\text { symalnie } 200 \% \\
\text { przeciętnego wyna- } \\
\text { grodzenia na po- } \\
\text { krycie kosztów } \\
\text { zamieszkania zwią- } \\
\text { zanych z podjęciem } \\
\text { zatrudnienia, innej } \\
\text { pracy zarobkowej } \\
\text { lub działalności } \\
\text { gospodarczej. }\end{array}$ & $\begin{array}{l}\text { Możliwość znalezienia } \\
\text { pracowników } \\
\text { z innych regionów. }\end{array}$ \\
\hline
\end{tabular}

Źródło: opracowanie własne.

\subsubsection{Bon szkoleniowy}

Zgodnie z art. 66k u.p.z. starosta może przyznać bon szkoleniowy, który stanowi gwarancję skierowania bezrobotnego na wskazane przez niego szkolenie oraz opłacenie kosztów, które zostaną poniesione w związku z podjęciem 
szkolenia (maksymalna wartość kosztów, które można pokryć z bonu szkoleniowego wynosi $100 \%$ przeciętnego wynagrodzenia obowiązującego w dniu przyznania bonu). W ramach bonu szkoleniowego mogą zostać sfinansowane koszty jednego lub kilku szkoleń, niezbędnych badań lekarskich lub psychologicznych, przejazdu i zakwaterowania. Podstawowa różnica pomiędzy szkoleniem inicjowanym i organizowanym przez starostę na zwykłych zasadach (art. 40 u.p.z.) a bonem szkoleniowym jest taka, że w ramach bonu bezrobotny sam dokonuje wyboru konkretnej oferty szkolenia. Aktywność zostaje przerzucona z urzędu pracy na młodego bezrobotnego, który powinien znaleźć szkolenie dające szanse na podjęcie zatrudnienia po jego ukończeniu. Poszukując pracy, bezrobotny może informować pracodawców o możliwości nabycia nowych/ specjalistycznych umiejętności, będzie zainteresowany, aby pracodawca zadeklarował chęć zatrudnienia go po odbytym szkoleniu, co z kolei zwiększy szanse na uzyskanie bonu. Dzięki takiemu rozwiązaniu pracodawca poszukujący kandydatów do pracy ma możliwość ustalenia z bezrobotnym, jakie szkolenie najlepiej przygotuje go do podjęcia pracy, a po ukończeniu szkolenia pozyska osobę dobrze przygotowaną (Ministerstwo Pracy 2014a: 8). W okresie odbywania szkolenia w ramach bonu młody bezrobotny ma prawo do stypendium w wysokości $120 \%$ zasiłku, o którym mowa w art. 72 ust. 1 pkt 1 u.p.z. (por. też art. 41 ust. 3 u.p.z.).

\subsubsection{Bon stażowy}

Bon stażowy, który został uregulowany w art. 661 u.p.z., stanowi z kolei gwarancję skierowania do odbycia stażu u pracodawcy wskazanego przez bezrobotnego na okres 6 miesięcy, o ile pracodawca zobowiąże się do zatrudnienia bezrobotnego na okres 6 miesięcy po zakończeniu stażu. Pracodawcy, który zatrudnia bezrobotnego przez deklarowany okres starosta wypłaca premię.

Staż jako instrument przeciwdziałania bezrobociu jest instytucją silnie zakorzenioną $\mathrm{w}$ ustawodawstwie rynku pracy. Po raz pierwszy pojawił się na gruncie ustawy o zatrudnieniu i przeciwdziałaniu bezrobociu z 1994 r. (Ustawa o zatrudnieniu i przeciwdziałaniu... 1994) w wyniku jednej z nowelizacji, której przepisy weszły w życie w marcu 1996 r. Dotychczas był jednak organizowany wyłącznie na zasadach określonych w art. 53 u.p.z. - inicjującym staż jest podmiot (organizator stażu), który zamierza przyjąć stażystę, który składa stosowny wniosek do starosty o zawarcie umowy o zorganizowanie stażu (Suknarowska-Drzewiecka 2010: 416). Staż trwa od 6 do 12 miesięcy (w zależności od kategorii bezrobotnych), nie jest jednak wymagane, aby po jego zakończeniu pracodawca zatrudnił stażystę. W przypadku bonu stażowego inicjatorem stażu jest młody bezrobotny, którego zadaniem jest znalezienie pracodawcy, który przyjmie go na staż, a po jego zakończeniu zatrudni na okres co najmniej 6 miesięcy. 
Bon stażowy daje większe pole do działania osobie bezrobotnej, która może wybrać sobie pracodawcę, u którego będzie odbywała staż, a następnie zostanie zatrudniona. Należy podkreślić, że chodzi tutaj o zatrudnienie w rozumieniu art. 2 ust. 1 pkt 43 u.p.z., tj. wykonywanie pracy na podstawie stosunku pracy, stosunku służbowego oraz umowy o pracę nakładczą. Zobowiązanie pracodawcy nie może odnosić się do zawarcia $\mathrm{z}$ bezrobotnym po odbyciu stażu umów cywilnoprawnych (umowy o dzieło, umowy zlecenia). Rozwiązanie takie należy ocenić jako bardzo korzystne. Przyjęcie nowego pracownika do pracy jest decyzją, która dla pracodawcy wiąże się z wieloma konsekwencjami na płaszczyźnie prawnej i ekonomicznej. Nieodpowiednie decyzje w tym zakresie mogą skutkować negatywnymi następstwami w obu tych sferach (Lipka 2002: 53). Niejednokrotnie pracodawcy z góry wykluczają możliwość zatrudnienia osób o określonych cechach socjodemograficznych, które - zdaniem podmiotów zatrudniających - zmniejszają wartość danych jednostek jako pracowników. Z pewnością zatrudnienie młodego, niedoświadczonego pracownika może generować takie obawy. W mojej ocenie mechanizm bonu stażowego jest doskonałym rozwiązaniem, które w znacznej mierze minimalizuje ryzyko osobowe pracodawcy i jednocześnie zachęca do zatrudniania osób młodych. Pracodawca przez 6 miesięcy ma możliwość wdrożenia młodego pracownika do pracy bez ponoszenia konsekwencji finansowych (bezrobotny otrzymuje w tym czasie stypendium w wysokości $120 \%$ kwoty zasiłku, o którym mowa w art. 72 ust. 1 pkt 1 u.p.z.). Dopiero po tym czasie zatrudnia bezrobotnego, wypłacając mu wynagrodzenie. Należy także pamiętać, że pracodawca ma zagwarantowaną premię w wysokości określonej w art. 661 ust. 4 u.p.z. Podmiot zatrudniający może bez ponoszenia kosztów przeszkolić stażystę zgodnie $\mathrm{z}$ własnymi potrzebami, a następnie - nawiązując $\mathrm{z}$ nim współpracę $\mathrm{w}$ ramach stosunku pracy - zyskać wykwalifikowanego pracownika (Staszewska 2013: 212). Poza szczególnymi warunkami skierowania na staż w trybie bonu (tzn. wybór pracodawcy przez bezrobotnego oraz zobowiązanie pracodawcy do zatrudnienia bezrobotnego po odbyciu stażu) do stażu odbywanego na podstawie bonu znajdują zastosowanie przepisy dot. „zwykłego stażu” (por. art. 661 ust. 9 u.p.z.).

\subsubsection{Bon zatrudnieniowy}

Trzecim typem bonu, jaki został przewidziany dla bezrobotnych do 30 . roku życia, jest bon zatrudnieniowy (art. 66m u.p.z.). Ten rodzaj bonu stanowi dla pracodawcy gwarancję refundacji części kosztów wynagrodzenia i składek na ubezpieczenia społeczne w związku z zatrudnieniem bezrobotnego, któremu powiatowy urząd pracy przyznał bon. Bon zatrudnieniowy jest przyznawany na wniosek bezrobotnego, jednak jego realizacja następuje na podstawie umowy zawieranej przez starostę $\mathrm{z}$ pracodawcą. $\mathrm{W}$ ramach umowy pracodawca zobo- 
wiązuje się do zatrudnienia młodego bezrobotnego na okres 18 miesięcy, przy czym okres pierwszych 12 miesięcy objęty jest refundacją części kosztów wynagrodzenia i składek na ubezpieczenie społeczne w wysokości zasiłku dla bezrobotnych, o którym mowa w art. 72 ust 1 pkt 1 u.p.z. (Rotkiewicz 2015: 432). Podobnie jak w przypadku bonu stażowego, zatrudnienie należy rozumieć jako wykonywanie pracy na podstawie stosunku pracy, stosunku służbowego oraz umowy o pracę nakładczą (a zatem niedopuszczalne jest zawieranie umów cywilnoprawnych). Wobec pracodawcy, który nie wywiąże się z obowiązku zatrudniania bezrobotnego przez okres 18 miesięcy przewidziane zostały sankcje polegające na zwrocie określonej kwoty refundacji (art. 66m ust. 9 u.p.z.). Jednocześnie jeżeli umowa o pracę zostanie rozwiązana z inicjatywy bezrobotnego lub pracodawca rozwiąże umowę o pracę w trybie art. 52 k.p., ewentualnie dojdzie do wygaśnięcia stosunku pracy, wówczas pracodawca nie będzie zwracał refundacji otrzymanej za okres zatrudnienia (art. 66m ust. 10 u.p.z.). Instytucja bonu zatrudnieniowego ma na celu zmobilizowanie młodego bezrobotnego do znalezienia pracodawcy, który zdecyduje się zatrudnić go na omówionych zasadach. $\mathrm{Z}$ kolei dla pracodawcy ma stanowić finansową zachętę do zatrudnienia danej osoby.

\subsubsection{Bon na zasiedlenie}

Ostatni rodzaj bonu (bon na zasiedlenie) ma na celu zwiększanie mobilności geograficznej młodych bezrobotnych. Zdolność do zmiany miejsca zamieszkania pod kątem istniejących w innym regionie możliwości zatrudnienia coraz częściej staje się kluczowym warunkiem pozwalającym na szybkie wyjście z bezrobocia (Staszewska 2012: 153). Jedną z cech charakterystycznych polskiego bezrobocia jest jego ogromne zróżnicowanie przestrzenne. Wiele regionów charakteryzuje się bardzo wysoką stopą bezrobocia, co powoduje, że ich mieszkańcy nie mają możliwości znalezienia zatrudnienia. Dobrym rozwiązaniem w takiej sytuacji jest bon na zasiedlenie. Starosta może przyznać ten bon na wniosek bezrobotnego w związku z zamiarem podjęciem przez niego zatrudnienia, innej pracy zarobkowej lub działalności gospodarczej poza miejscem dotychczasowego zamieszkania, $\mathrm{W}$ art. 66 n ust. 1 u.p.z. wskazane zostały warunki, których spełnienie przez bezrobotnego w przyszłości uzasadnia przyznanie bonu na zasiedlenie (m.in. konieczność osiągania określonego wynagrodzenia lub przychodu, odpowiednia odległość od miejsca dotychczasowego zamieszkania oraz czas pozostawania w zatrudnieniu czy prowadzenie działalności gospodarczej). Maksymalna wysokość środków, jakie mogą zostać przyznane w ramach bonu na zasiedlenie to dwukrotność przeciętnego wynagrodzenia za pracę. Mogą one zostać przeznaczone jedynie na pokrycie kosztów zamieszkania związanych z podjęciem zatrudnienia, innej pracy zarobkowej lub działalności gospodarczej. 


\subsection{Refundacja składek na ubezpieczenie społeczne}

Kolejnym instrumentem mającym za zadanie zwiększyć szanse zatrudnienia bezrobotnych do 30. roku życia jest refundacja kosztów składek na ubezpieczenie społeczne. W przypadku tego instrumentu ustawodawca ograniczył jego zakres podmiotowy wyłącznie do bezrobotnych, którzy podejmują zatrudnienie po raz pierwszy w życiu (art. 60c u.p.z.). Chodzi o osoby, które dotychczas nie pozostawały w zatrudnieniu w znaczeniu, jakie temu pojęciu nadaje art. 2 ust. 1 pkt 43 u.p.z., a zatem nie pozostawały w stosunku pracy, stosunku służbowym oraz nie były zatrudnione na podstawie umowy o pracę nakładczą. Warto zauważyć, że skorzystanie z tego instrumentu nie będzie wyłączone, jeśli młody bezrobotny wcześniej świadczył pracę na podstawie umów cywilnoprawnych bądź też prowadził działalność gospodarczą. Brak wcześniejszego zatrudnienia wśród osób szukających pracy generuje wysokie ryzyko osobowe obciążające pracodawcę, który obawia się braku doświadczenia zawodowego. Związane z zatrudnieniem ludzi młodych ryzyko osobowe może zostać zrekompensowane poprzez obniżanie kosztów takiego zatrudnienia. Koszty te są kreowane przede wszystkim przez wynagrodzenia, a także przez obciążenia finansowe związane z koniecznością opłacania składek ubezpieczeniowych i dokonywania innych opłat (Góral 2006: 120). Takie rozwiązanie wprowadzone zostało $\mathrm{w}$ art. 60c u.p.z. Starosta może na podstawie zawartej umowy refundować pracodawcy koszty poniesione na składki na ubezpieczenia społeczne należne od pracodawcy za skierowanych do pracy bezrobotnych do 30. roku życia, którzy podejmują zatrudnienie po raz pierwszy w życiu. Refundacja kosztów poniesionych na składki na ubezpieczenia społeczne przysługuje przez okres do 12 miesięcy w kwocie określonej w umowie, nie wyższej jednak niż połowa minimalnego wynagrodzenia za pracę miesięcznie obowiązującego w dniu zawarcia umowy za każdego zatrudnionego bezrobotnego. Pracodawca jest obowiązany do dalszego zatrudniania skierowanego bezrobotnego przez 6 miesięcy po zakończeniu okresu refundacji kosztów poniesionych na składki na ubezpieczenia społeczne. Ustawodawca zadbał jednocześnie o uregulowanie przypadków wcześniejszego rozwiązania przez pracodawcę umów o pracę, wprowadzając sankcję w postaci zwrotu otrzymanej kwoty (wysokość uzależniona została od długości zatrudnienia - por. art. 60c ust. 4-5 u.p.z.). Jeżeli umowa o pracę zostanie rozwiązana przez bezrobotnego lub dojdzie do rozwiązania z nim umowy w trybie art. 52 k.p, ewentualnie wygaśnięcia stosunku pracy w trakcie okresu objętego refundacją albo przed upływem 6 miesięcy, w których pracodawca był zobowiązany do dalszego zatrudniania skierowanego bezrobotnego, starosta kieruje na zwolnione stanowisko innego bezrobotnego (art. 60c ust. 6 u.p.z.). Celem takiego rozwiązania jest doprowadzenie do zagwarantowania jak najdłuższego utrzymania miejsca pracy. Zadaniem przedmiotowej refundacji jest przede wszystkim ułatwienie wejścia na rynek pracy młodym osobom bez doświadczenia zawodowego. 


\subsection{Czasowe wyłączenie obowiązku opłacania składek na Fundusz Pracy}

Warto wreszcie zwrócić uwagę na ostatni nowy instrument mający wspierać zatrudnienie młodych bezrobotnych. Na podstawie art. 104c u.p.z. pracodawcy oraz inne jednostki organizacyjne nie opłacają składek na Fundusz Pracy przez okres 12 miesięcy (począwszy od pierwszego miesiąca po zawarciu umowy o pracę) za skierowanych zatrudnionych bezrobotnych, którzy nie ukończyli 30 . roku życia. Zadaniem tego zwolnienia jest zachęcenie pracodawców do oferowania miejsc pracy bezrobotnym w tej grupie wiekowej i ułatwienie im tym samym wejścia na rynek pracy.

\section{INSTRUMENTY RYNKU PRACY DLA OSÓB BEZROBOTNYCH POWYŻEJ 50. ROKU ŻYCIA}

Drugą grupą bezrobotnych, dla których ustawodawca zdecydował się na wprowadzenie nowych instrumentów rynku pracy są osoby powyżej 50. roku życia. Wiek nie jest na rynku pracy czynnikiem sprzyjającym ani dla osób młodych ze względu na brak doświadczenia zawodowego, ani dla starszych, którzy pomimo posiadanego doświadczenia mają trudności z utrzymaniem się na rynku pracy (Urbaniak 2007: 10). Z danych statystycznych wynika, że w końcu I kwartału 2016 r. aż $28,6 \%$ spośród wszystkich bezrobotnych były to osoby w wieku powyżej 50 roku życia. Ustawodawca już w pierwotnej wersji ustawy o promocji zatrudnienia i instytucjach rynku pracy traktował bezrobotnych powyżej 50 roku życia jako grupę ryzyka na rynku pracy, oferując jednocześnie dodatkowe instrumenty wyłącznie tej grupie (Kryńska 2006: 3). Warto w tym miejscu wskazać choćby na prace interwencyjne. Osoby bezrobotne powyżej 50 roku życia mogą być do nich kierowane na okres nawet 4 lat. Pracodawca, który zatrudni bezrobotnych w tej grupie wiekowej w ramach prac interwencyjnych, może liczyć na refundację poniesionych kosztów na wynagrodzenia i składki na ubezpieczenia społeczne (art. 59 u.p.z.). Nowym rozwiązaniem, jakie pojawiło się na skutek nowelizacji (Ustawa o zmianie... 2014) jest przewidziane w art. 60d u.p.z. dofinansowanie wynagrodzenia za zatrudnienie bezrobotnego, który ukończył 50 lat. Starosta na podstawie zawartej umowy może przyznać pracodawcy lub przedsiębiorcy dofinansowanie: na okres 12 miesięcy w przypadku zatrudnienia bezrobotnego, który ukończył 50 lat, a nie ukończył 60 lat; na okres 24 miesięcy - jeżeli zatrudnienie dotyczy bezrobotnego, który ukończył 60 lat. Dofinansowanie wynagrodzenia przysługuje $\mathrm{w}$ kwocie określonej w umowie, nie wyższej jednak niż połowa minimalnego wynagrodzenia za pracę miesięcznie obowiązującego w dniu zawarcia umowy, za każdego zatrudnionego bezrobotnego. Pracodawca lub przedsiębiorca są obowiązani do dalszego zatrudniania skierowanego bezrobotnego po upływie okresu przysługiwania dofinansowania wynagrodzenia, odpowiednio przez 6 lub 12 miesięcy w zależności od wieku osoby bezrobotnej (poniżej lub 
powyżej 60 lat). Jednocześnie ustawodawca przewidział sankcje w przypadku niedotrzymania warunku zatrudnienia w postaci konieczności zwrotu otrzymanych środków (wysokość uzależniona została od długości zatrudnienia - por. art. 60d ust. 5 i 6 u.p.z.). W przypadku rozwiązania umowy o pracę przez skierowanego bezrobotnego, rozwiązania z nim umowy w trybie art. 52 k.p. lub wygaśnięcia stosunku pracy $\mathrm{w}$ trakcie okresu objętego dofinansowaniem albo przed upływem okresu odpowiednio 6 lub 12 miesięcy, starosta kieruje na zwolnione stanowisko innego bezrobotnego (art. 60d ust. 7 u.p.z.).

\section{INSTRUMENTY RYNKU PRACY DLA OSÓB BEZROBOTNYCH POWRACAJACCYCH NA RYNEK PRACY PO PRZERWIE ZWIĄZANEJ Z WYCHOWYWANIEM DZIECKA LUB SPRAWOWANIEM OPIEKI NAD OSOBĄ ZALEŻNĄ}

Ostatnią grupą bezrobotnych, dla której ustawodawca zdecydował się skonstruować nowe instrumenty wsparcia, są osoby powracające na rynek pracy po przerwie związanej $\mathrm{z}$ wychowywaniem dziecka lub sprawowaniem opieki nad osobą zależną. W przypadku tej grupy szczególnie trudna sytuacja na rynku pracy podyktowana jest sytuacją życiową. Okolicznością potęgującą problemy ze znalezieniem pracy jest czasowe oderwanie od środowiska pracy powodujące utratę szeroko rozumianej mobilności zawodowej. Dotyczy to osób, które $\mathrm{z}$ różnych powodów przestały być na pewien czas aktywne zawodowo, a następnie chcą powrócić na rynek pracy (Staszewska 2012: 108).

Przerwy w aktywności zawodowej utrudniają wejście na rynek pracy, zwiększając tym samym ryzyko zastania bezrobotnym. Celem wprowadzonych do ustawy o promocji zatrudnienia nowych instrumentów (grant na telepracę oraz świadczenie aktywizacyjne), jest umożliwienie pogodzenia obowiązków rodzinnych z zawodowymi i ułatwienie powrotu do zatrudnienia.

\subsection{Grant na telepracę}

Grant na telepracę został uregulowany w art. 60a u.p.z. Z przywołanego przepisu wynika, że starosta może na podstawie zawartej umowy przyznać pracodawcy lub przedsiębiorcy środki Funduszu Pracy na utworzenie stanowiska pracy w formie telepracy w rozumieniu art. $67^{5} \mathrm{k}$.p. dla skierowanego bezrobotnego. Ustawodawca zawęził grupę bezrobotnych, dla których może być tworzone stanowisko, wyłącznie do rodziców powracających na rynek pracy, posiadających co najmniej jedno dziecko w wieku do 6 lat lub bezrobotnych sprawujących opiekę nad osobą zależną ${ }^{3}$, którzy wokresie 3 lat przed rejestracją

${ }^{3}$ Osoba zależna zgodnie z art. 2 ust. 1 pkt 21 u.p.z. oznacza osobę wymagającą ze względu na stan zdrowia lub wiek stałej opieki, połączoną więzami rodzinnymi lub powinowactwem $\mathrm{z}$ osobą objętą usługami lub instrumentami rynku pracy, lub pozostającą we wspólnym gospodarstwie domowym. 
w urzędzie pracy jako bezrobotni zrezygnowali z zatrudnienia lub innej pracy zarobkowej z uwagi na konieczność wychowywania dziecka lub sprawowania opieki nad osobą zależną. Stanowisko pracy musi być tworzone do świadczenia pracy w formie telepracy. Zgodnie z art. $67^{5}$ k.p. chodzi o regularne wykonywanie pracy poza zakładem pracy z wykorzystaniem środków komunikacji elektronicznej w rozumieniu przepisów o świadczeniu usług drogą elektroniczną. Jak wynika z art. 2 pkt 5 ustawy z dnia 18 lipca 2002 r. o świadczeniu usług drogą elektroniczną (Ustawa o świadczeniu ustug... 2002) są to rozwiązania techniczne, w tym urządzenia teleinformatyczne i współpracujące z nimi narzędzia programowe, umożliwiające indywidualne porozumiewanie się na odległość przy wykorzystaniu transmisji danych między systemami teleinformatycznymi, a w szczególności pocztę elektroniczną. Grant przysługuje w kwocie określonej w umowie zawartej ze starostą, nie wyższej jednak niż 6-krotność minimalnego wynagrodzenia za pracę obowiązującego w dniu zawarcia umowy za każdego skierowanego bezrobotnego. Pracodawca lub przedsiębiorca są obowiązani, stosownie do zawartej umowy, do utrzymania zatrudnienia skierowanego bezrobotnego przez okres 12 miesięcy w pełnym wymiarze czasu pracy lub przez okres 18 miesięcy w połowie wymiaru czasu pracy. Niewywiązanie się z powyższego warunku, wykorzystanie grantu niezgodnie $\mathrm{z}$ umową lub jego niewykorzystanie powoduje obowiązek zwrotu grantu; wysokość uzależniona została od długości zatrudnienia (por. art. 60a ust. 5 i 6 u.p.z.). W przypadku rozwiązania umowy o pracę przez skierowanego bezrobotnego, rozwiązania z nim umowy w trybie art. 52 k.p. lub wygaśnięcia stosunku pracy przed upływem okresu odpowiednio 12 lub 18 miesięcy starosta kieruje na zwolnione stanowisko innego bezrobotnego (art. 60a ust. 7 u.p.z.). W związku z sytuacją życiową osób bezrobotnych, dla których ma być tworzone stanowisko pracy w formie telepracy, należy zwrócić uwagę na korzyści, jakie wiążą się z tą formą aktywizacji zawodowej. Przede wszystkim telepraca stwarza możliwość zatrudnienia dla osób, które ze względów rodzinnych nie mogą opuszczać mieszkania, dla których tradycyjne formy pracy związane z koniecznością dojazdu do zakładu pracy i przebywania w nim przez większą część dnia są niedostępne (osoby opiekujące się dziećmi, chorymi członkami rodziny, osoby niepełnosprawne, Rotkiewicz 2015: 325). Z drugiej strony należy jednak mieć na uwadze, że nie każdy rodzaj pracy może być wykonywany w formie telepracy, co powoduje, że ten instrument przeciwdziałania bezrobociu ma ograniczony zasięg. Choć prace możliwe do wykonywania w formie telepracy są zróżnicowane, to często wymagają wysokich kwalifikacji i specjalistycznej wiedzy (Bąk 2009: 122). Stąd też nie należy przeceniać roli grantu na telepracę jako środka przeciwdziałania bezrobociu. 


\section{2. Świadczenie aktywizacyjne}

Drugim instrumentem rynku pracy skierowanym do osób bezrobotnych powracających na rynek pracy po przerwie związanej z wychowywaniem dziecka lub sprawowaniem opieki nad osobą zależną jest świadczenie aktywizacyjne. Zgodnie $\mathrm{z}$ art. $60 \mathrm{~b}$ u.p.z. starosta na podstawie zawartej umowy może przyznać pracodawcy świadczenie aktywizacyjne za zatrudnienie w pełnym wymiarze czasu pracy bezrobotnego rodzica powracającego na rynek pracy po przerwie związanej $\mathrm{z}$ wychowywaniem dziecka lub bezrobotnego sprawującego opiekę nad osobą zależną, który w okresie 3 lat przed rejestracją w urzędzie pracy jako bezrobotny zrezygnował z zatrudnienia lub innej pracy zarobkowej z uwagi na konieczność wychowywania dziecka lub sprawowania opieki nad osobą zależną. Świadczenie aktywizacyjne może przysługiwać przez okres 12 miesięcy w wysokości połowy minimalnego wynagrodzenia za pracę miesięcznie za każdego skierowanego bezrobotnego albo 18 miesięcy w wysokości jednej trzeciej minimalnego wynagrodzenia za pracę miesięcznie za każdego skierowanego bezrobotnego. Podobnie jak to miało miejsce $\mathrm{w}$ większości omawianych wcześniej nowych instrumentów rynku pracy, również w przypadku świadczenia aktywizacyjnego pracodawca jest obowiązany do dalszego zatrudniania skierowanego bezrobotnego po upływie okresu przysługiwania świadczenia. W zależności od tego, czy świadczenie aktywizacyjne zostało przyznane na okres 12 czy 18 miesięcy, pracodawca zobowiązany jest do dalszego zatrudniania bezrobotnego odpowiednio przez okres 6 lub 9 miesięcy. Sankcją za rozwiązanie przez pracodawcę umowy o pracę $w$ trakcie przysługiwania świadczenia aktywizacyjnego lub niewywiązanie się $\mathrm{z}$ warunku utrzymania osoby w zatrudnieniu przez okres odpowiednio 6 lub 9 miesięcy przypadających po ustaniu prawa do tego świadczenia jest zwrot otrzymanych świadczeń aktywizacyjnych; wysokość uzależniona została od długości utrzymania zatrudnienia (por. art. 60b ust. 4-5 u.p.z.). Jeżeli dojdzie do rozwiązania umowy o pracę przez skierowanego bezrobotnego, rozwiązania z nim umowy w trybie art. 52 k.p. lub wygaśnięcia stosunku pracy w trakcie przysługiwania świadczenia aktywizacyjnego albo przed upływem okresu odpowiednio 6 lub 9 miesięcy, starosta kieruje na zwolnione stanowisko pracy innego bezrobotnego (art. $60 \mathrm{~b}$ ust. 6 u.p.z.).

\section{WYNIKI BADAŃ DOTYCZĄCYCH AKTYWIZACJI GRUP DEFAWORYZOWANYCH NA RYNKU PRACY W RAMACH NOWYCH FORM WSPARCIA}

Ministerstwo Rodziny, Pracy i Polityki Społecznej (Ministerstwo Rodziny, Pracy i Polityki Społecznej 2016) dokonało analizy rozwiązań wprowadzonych w wyniku nowelizacji (Ustawa o zmianie... 2014) pod kątem liczby osób bezrobotnych, które rozpoczęły aktywizację w ramach nowych form wsparcia. 
Tabela 2. Liczba osób bezrobotnych do 30. roku życia, które rozpoczęły aktywizację w ramach nowych form wsparcia

\begin{tabular}{|l|c|c|c|c|}
\hline \multicolumn{5}{|c|}{ Przedział czasowy } \\
\hline \multicolumn{1}{|c|}{ Rodzaj aktywizacji } & $\begin{array}{c}27.05 .2014 \text { r. }- \\
31.12 .2014 \text { r. }\end{array}$ & 2015 r. & $\begin{array}{c}\text { styczeń-maj } \\
2016 \text { r. }\end{array}$ & Razem \\
\hline $\begin{array}{l}\text { Rozpoczęcie stażu w ramach } \\
\text { bonu stażowego }\end{array}$ & 10176 & 9054 & 1784 & $\mathbf{2 1 ~ 0 1 4}$ \\
\hline $\begin{array}{l}\text { Rozpoczęcie szkolenia } \\
\text { w ramach bonu szkoleniowego }\end{array}$ & 2475 & 5942 & 2186 & $\mathbf{1 0 ~ 6 0 3}$ \\
\hline $\begin{array}{l}\text { Podjęcie pracy w ramach } \\
\text { bonu zatrudnieniowego }\end{array}$ & 1599 & 3239 & 565 & $\mathbf{5 4 0 3}$ \\
\hline $\begin{array}{l}\text { Podjęcie pracy poza miej- } \\
\text { scem zamieszkania w ramach } \\
\text { bonu na zasiedlenie }\end{array}$ & 1334 & 6804 & 3916 & $\mathbf{1 2 ~ 0 5 4}$ \\
\hline $\begin{array}{l}\text { Podjęcie działalności gospo- } \\
\text { darczej w ramach bonu na } \\
\text { zasiedlenie }\end{array}$ & 42 & 123 & 70 & $\mathbf{2 3 5}$ \\
\hline $\begin{array}{l}\text { Refundacja składek na ubez- } \\
\text { pieczenia społeczne należne } \\
\text { od pracodawcy za bezrobot- } \\
\text { nych do 30 r. życia podejmu- } \\
\text { jących zatrudnienie po raz } \\
\text { pierwszy w życiu }\end{array}$ & 29 & 44 & 308 & $\mathbf{3 8 1}$ \\
\hline
\end{tabular}

Źródło: opracowano na podstawie: Ministerstwo Rodziny, Pracy i Polityki Społecznej 2016: 11.

Analiza danych zawartych w powyższej tabeli (tabela 2) pozwala stwierdzić, że wśród młodych bezrobotnych największą popularnością cieszy się bon stażowy. Jest to spowodowane w dużej mierze silnym zakorzenieniem stażu dla bezrobotnych w polskim ustawodawstwie z zakresu bezrobocia - instrumentu znanego i cieszącego się dobrą opinią wśród pracodawców przede wszystkim z uwagi na brak ponoszenia przez nich jakichkolwiek konsekwencji finansowych w związku z przyjęciem bezrobotnego. Choć w przypadku bonu stażowego pracodawca zostaje zobowiązany do dalszego zatrudnienia bezrobotnego po zakończeniu stażu, to jednak wiąże się z tym otrzymanie premii, a okres zatrudnienia jest stosunkowo krótki.

Nie dziwi niewielkie wykorzystanie bonu zatrudnieniowego. Przy tym instrumencie mamy do czynienia z koniecznością zatrudnienia młodego bezrobotnego na dość długi okres (18 miesięcy) oraz z określonymi sankcjami dla pracodawcy, który nie dotrzyma tego obowiązku. Dlatego pracodawcy niechętnie przyjmują młodych bezrobotnych.

Zainteresowanie bonem na zasiedlenie jest z kolei bezpośrednio związane z mobilnością geograficzną młodych bezrobotnych zdolnych do podjęcia poza miejscem dotychczasowego zamieszkania zatrudnienia bądź innej pracy zarobkowej. 
Bon szkoleniowy jest instrumentem, który nie wywołuje bezpośrednio skutku w postaci zatrudnienia młodego bezrobotnego. Jest to środek, który ma jedynie ułatwić podjęcie zatrudnienia w przyszłości dzięki uzyskaniu czy uzupełnieniu umiejętności i kwalifikacji zawodowych. Skuteczność tego instrumentu należy zatem oceniać z punktu widzenia podjęcia zatrudnienia po ukończeniu szkolenia. Dla przykładu w 2015 r. szkolenie ukończyły 5884 osoby. W okresie do 3 miesięcy po zakończeniu szkolenia pracę podjęło $70,9 \%$ posiadaczy bonu szkoleniowego, co pozwala pozytywnie ocenić bony szkoleniowe (Ministerstwo Rodziny, Pracy i Polityki Społecznej 2016: 129).

Jeżeli chodzi o nowy instrument w postaci refundacji składek na ubezpieczenia społeczne, to wprowadzone rozwiązanie miało ułatwić podejmowanie pracy przez młode osoby, które do tej pory nie były zatrudnione, w związku $\mathrm{z}$ czym nie posiadają doświadczenia zawodowego. $\mathrm{Z}$ danych zawartych $\mathrm{w}$ tabeli 2 wynika, że instrument ten nie cieszył się w badanym okresie dużym zainteresowaniem pracodawców. O ile w przypadku systemu bonów inicjatywa znalezienia pracodawcy czy instytucji szkoleniowej należy do młodego bezrobotnego, o tyle $\mathrm{w}$ przypadku refundacji składek to pracodawca zawiera odpowiednią umowę ze starostą. Niewielki stopień wykorzystania tego instrumentu wynika z konieczności dość długiego utrzymania bezrobotnego w zatrudnieniu i niewielką kwotą refundacji, a także braku bezrobotnych spełniających ustawowe kryterium podjęcia zatrudnienia po raz pierwszy w życiu (Ministerstwo Rodziny, Pracy i Polityki Społecznej 2016: 119).

Dofinansowanie wynagrodzenia za zatrudnionego bezrobotnego powyżej 50. roku życia ma na celu aktywizację zawodową tej grupy osób w związku z dającym się wyraźnie zaobserwować zjawiskiem polegającym na tym, że z wiekiem zmniejsza się zarówno współczynnik aktywności zawodowej, jak i wskaźnik zatrudnienia. Podejmowane działanie ma złagodzić te negatywne tendencje, umożliwiając grupie starszych bezrobotnych utrzymanie się na rynku pracy jak najdłużej (często do osiągnięcia uprawnień emerytalnych). $\mathrm{Z}$ danych zawartych w tabeli 3 wynika, że wykorzystanie tego instrumentu systematycznie wzrasta. Często w przypadku subsydiowanych form zatrudnienia zwraca się uwagę, że przyjęcie skierowanych bezrobotnych stanowi dla pracodawców znaczną oszczędność kosztów osobowych ze względu na obniżenie ceny siły roboczej dzięki refundacjom (Bednarski 1999: 23). Taka forma wsparcia może jednak wywoływać określone negatywne konsekwencje, jak chociażby efekt ,jałowego biegu”, który polega na osiągnięciu przez dany program stymulacji zatrudnienia skutków, które powstałyby także bez jego działania - zatrudnienie osób, które i tak zostałyby zatrudnione. Drugim niepokojącym zjawiskiem może być efekt substytucji, polegający na zastępowaniu w przedsiębiorstwach pracowników zatrudnionych na zasadach rynkowych przez pracowników uczestniczących w programach dofinansowania, których zatrudnienie jest dla pracodawców 
tańsze (Skąpski 2006: 204). W mojej ocenie wspomniane wyżej negatywne skutki w mniejszym zakresie będą występowały w przypadku osób powyżej 50 . roku życia, których sytuacja na rynku pracy jest szczególnie niekorzystna. Ewentualnie widziałabym zagrożenie efektem ,jałowego biegu”, choć i tutaj ryzyko jest niewielkie. Pracodawca zatrudnia bowiem grupę defaworyzowaną, nie zaś grupę dowolnie przez siebie dobraną.

Tabela 3. Liczba osób bezrobotnych powyżej 50. roku życia, które rozpoczęły aktywizację w ramach nowych form wsparcia

\begin{tabular}{|l|c|c|c|c|}
\hline \multicolumn{5}{|c|}{ Przedział czasowy } \\
\hline \multicolumn{1}{|c|}{ Rodzaj aktywizacji } & $\begin{array}{c}27.05 .2014 \\
-31.12 .2014\end{array}$ & 2015 & styczeń-maj 2016 & Razem \\
\hline $\begin{array}{l}\text { Podęcie pracy w ramach } \\
\text { dofinansowania wynagro- } \\
\text { dzenia za zatrudnienie skie- } \\
\text { rowanego bezrobotnego } \\
\text { powyżej 50. roku życia. }\end{array}$ & 1196 & 2759 & 1832 & $\mathbf{5 7 8 7}$ \\
\hline
\end{tabular}

Źródło: opracowano na podstawie: Ministerstwo Rodziny, Pracy i Polityki Społecznej 2016: 11.

Najmniej korzystnie prezentują się dane dotyczące wykorzystania nowych instrumentów rynku pracy dla osób bezrobotnych powracających na rynek pracy po przerwie związanej z wychowywaniem dziecka lub sprawowaniem opieki nad osobą zależną. Łącznie w okresie od dnia wejścia w życie nowelizacji ustawy do końca maja $2016 \mathrm{r}$. w ramach obu instrumentów zatrudnienie podjęło jedynie 88 osób (tabela 4). Na podstawie zgromadzonych danych można stwierdzić, że większym zainteresowaniem pracodawców cieszyło się świadczenie aktywizacyjne. Jest to spowodowane przede wszystkim małą popularnością świadczenia pracy w formie telepracy w Polsce. Jak było wcześniej podkreślane, wykonywanie pracy w tej formie nie jest możliwe w przypadku każdego rodzaju pracy, co znacznie ogranicza zasięg grantu. Utrudnieniem są też skomplikowane przepisy kodeksu pracy regulujące telepracę. Choć ta forma pracy wydaje się idealna dla osób chcących pogodzić pracę z obowiązkami rodzinnymi, to jednak problemem może okazać się znalezienie pracodawcy, który zaoferuje możliwość świadczenia pracy $\mathrm{w}$ domu pracownika. W związku $\mathrm{z}$ niewielkim stopniem w jakim dotychczas wykorzystano grant na telepracę i świadczenie aktywizacyjne trudno dokonać jednoznacznego osądu wprowadzonych instrumentów. Niemniej każde nowo utworzone miejsce pracy, zwłaszcza dla bezrobotnych, którzy na dłuższy czas zostali wyłączeni z rynku pracy, należy ocenić pozytywnie. 
Tabela nr 4. Liczba osób bezrobotnych powracających na rynek pracy po przerwie związanej $\mathrm{z}$ wychowywaniem dziecka lub sprawowaniem opieki nad osobą zależną, które rozpoczęły aktywizację w ramach nowych form wsparcia

\begin{tabular}{|l|c|c|c|c|}
\hline \multicolumn{5}{|c|}{ Przedział czasowy } \\
\hline \multicolumn{1}{|c|}{ Rodzaj aktywizacji } & $\begin{array}{c}27.05 .2014 \\
-31.12 .2014\end{array}$ & 2015 & styczeń-maj 2016 & Razem \\
\hline $\begin{array}{l}\text { Podjęcie pracy w ramach grantu na } \\
\text { telepracę }\end{array}$ & 2 & 6 & 0 & $\mathbf{8}$ \\
\hline $\begin{array}{l}\text { Podjęcie pracy w ramach świadcze- } \\
\text { nia aktywizacyjnego }\end{array}$ & 29 & 39 & 12 & $\mathbf{8 0}$ \\
\hline
\end{tabular}

Źródło: opracowano na podstawie: Ministerstwo Rodziny, Pracy i Polityki Społecznej 2016: 11.

\section{PODSUMOWANIE}

Dane statystyczne jednoznacznie wskazują na szczególne zagrożenie bezrobociem niektórych osób pozostających poza zatrudnieniem. Poprzestanie na zapewnieniu takiej samej pomocy w uzyskaniu zatrudnienia wszystkim bezrobotnych spowodowałoby osłabienie możliwość realizacji prawa do pracy w odniesieniu do pewnych kategorii osób, w przypadku których ryzyko bezrobocia jest szczególnie wysokie (Góral 1994: 184). Różna sytuacja na rynku pracy poszczególnych grup bezrobotnych musi prowadzić w konsekwencji do dyferencjacji ich statusu prawnego. Polski ustawodawca dostrzega tę potrzebę, czego dowodem są nowe instrumenty rynku wprowadzone na skutek ostatniej nowelizacji ustawy o promocji zatrudnienia i instytucjach rynku pracy. Ich zasadniczym celem jest pomoc $w$ wejściu na rynek pracy i utrzymaniu się na nim osobom młodym (do 30. roku życia) oraz osobom starszym (powyżej 50. roku życia) przede wszystkim poprzez wsparcie pracodawców zatrudniających wskazane grupy bezrobotnych. Wśród zaproponowanych przez ustawodawcę nowych instrumentów rynku pracy dla dwóch grup bezrobotnych wyodrębnionych ze względu na wiek szczególnie pozytywnie należy ocenić system bonów dla osób młodych. Po raz pierwszy prawodawca zaproponował innowacyjne rozwiązanie polegające na oddaniu inicjatywy znalezienia pracodawcy czy instytucji szkoleniowej samemu bezrobotnemu, co w mojej ocenie zachęca młodych bezrobotnych do bardziej aktywnej postawy w poszukiwaniu pracy. Ponadto pozwala im na bezpośrednie, wstępne zaprezentowanie się przed potencjalnym pracodawcą, co może wpłynąć na ewentualną decyzję o przyjęciu ich do pracy. Pozytywnie oceniam bon stażowy, w ramach którego bezrobotny bez nawiązywania stosunku pracy może nabyć umiejętności praktyczne do wykonywania pracy u danego podmiotu (jednocześnie mając zapewnione stypendium), a następnie zostaje zatrudniony u danego pracodawcy, który przez okres stażu w znaczny sposób może zminimalizować ryzyko osobowe, wyszkolić pracownika zgodnie ze swo- 
imi potrzebami. Równie wysoko oceniam bon zatrudnieniowy, choć w tym przypadku pewnym ograniczeniem jest niechęć pracodawców do zatrudniania młodych bezrobotnych na stosunkowo długi okres niepoprzedzony pozapracowniczą formą sprawdzenia przydatności zawodowej bezrobotnego. Wprowadzone nowe instrumenty mają wpływ na rynek pracy, w tym na poprawę wskaźników zatrudnieniowych wśród osób młodych. Dzięki nowym instrumentom aktywizacyjnym urzędy pracy dysponują także większymi możliwościami pomocy osobom młodym.

Jeżeli chodzi o dofinansowanie zatrudnienia osób bezrobotnych powyżej 50 lat, trudno mówić o jakimś nowatorskim rozwiązaniu, albowiem w ustawie o promocji zatrudnienia funkcjonują już inne, podobne formy subsydiowania zatrudnienia. Ewentualna pozytywna ocena wiąże się z faktem wprowadzenia dodatkowego instrumentu wsparcia zatrudnienia pracowników 50 plus.

Nowe narzędzia mają za zadanie także wspieranie tworzenia miejsc pracy dla osób bezrobotnych powracających na rynek pracy po przerwie związanej $\mathrm{z}$ wychowywaniem dziecka lub sprawowaniem opieki nad osobą zależną. Za w pełni uzasadnione należy uznać traktowanie osób posiadających dzieci jako znajdujących się w szczególnej sytuacji na rynku pracy i konstruowanie dla tej grupy specjalnie dostosowanych do ich problemów instrumentów rynku pracy. Szczególnego znaczenia nabierają rozwiązania nie tylko wspomagające tworzenie miejsc pracy poprzez częściowe refundacje, jak np. świadczenie aktywizacyjne, ale także sprzyjające godzeniu obowiązków zawodowych i rodzinnych, jak grant na telepracę. Okazuje się jednak, że wprowadzone instrumenty nie zawsze są dostosowane do polskich realiów - szczególnie widoczne jest to w przypadku grantu na telepracę. Instrument ten może przynieść najwięcej korzyści, jeżeli praca będzie świadczona w domu rodzica-telepracownika, który będzie mógł dostosować rytm i czas pracy do własnych możliwości i nie będzie zmuszony dojeżdżać do pracy. Podstawowym warunkiem popularności i skuteczności tego instrumentu jest jednak możliwość tworzenia miejsc pracy, w których praca może być świadczona w formie telepracy. Niestety nie każdy rodzaj pracy może odbywać się w tej formie, co powoduje, że telepraca stanowi szansę na zatrudnienie tylko dla niektórych grup bezrobotnych. Niejednokrotnie potrzebne są również szczególne kwalifikacje do wykonywania telepracy, co ogranicza zasięg tego instrumentu ( $\mathrm{w}$ dalszym ciągu znaczna grupa polskich bezrobotnych to ludzie słabo wykształceni, o niskich kwalifikacjach). Wszystko to powoduje, że grant na telepracę należy do najsłabiej wykorzystanych nowych instrumentów rynku pracy. Nie oznacza to jednak, moim zdaniem, że należy zrezygnować z tej formy wsparcia. Potrzebna jest kampania, która zachęciłaby pracodawców do korzystania z elastycznych form organizacji pracy.

W przypadku osób, które napotykają na szczególne trudności ze znalezieniem pracy, niezbędne jest znalezienie rozwiązań, które zachęcą pracodawców 
do zatrudnienia danej osoby. Tworzenie systemu wsparcia finansowego dla pracodawców, którzy zatrudnią bezrobotnych z grup defaworyzowanych może w dość istotnym stopniu wpłynąć na szanse ich zaktywizowania zawodowego. Choć wskazane nowe instrumenty rynku pracy nie są pozbawione wad, to stanowią zapowiedź coraz lepszego dostosowywania pomocy do rzeczywistych potrzeb osób, które mają problemy z pozyskaniem zatrudnienia na konkurencyjnym rynku pracy.

\section{BIBLIOGRAFIA}

Bąk E. (2009), Nietypowe formy zatrudnienia na rynku pracy, Warszawa.

Bednarski M. (1999), Aktywne formy przeciwdziałania bezrobociu w Polsce. Narzędzia i instytucje. Warszawa.

Główny Urząd Statystyczny (2016), Bezrobocie rejestrowane IV kwartał $2016 r$. Informacje i opracowania statystyczne, Warszawa.

Góral Z. (1994), Prawo do pracy. Studium prawa polskiego w świetle porównawczym, Łódź.

Góral Z. (2002a), Dyferencjacja statusu prawnego bezrobotnych, [w:] Prawo pracy a wyzwania XXI wieku. Ksiega Jubileuszowa Profesora Tadeusza Zielińskiego, Warszawa.

Góral Z. (2002b), Rola prawa w przeciwdziałaniu bezrobociu, [w:] M. Seweryński, J. Wojtyła, Społeczne aspekty bezrobocia. Skutki i przeciwdziałanie, Katowice.

Góral Z. (2006), Prawo do pierwszej pracy (z prawnych zagadnień promowania zatrudnienia i przeciwdziałania bezrobociu), [w:] M. Matey-Tyrowicz, T. Zielińskiego (red.), Prawo pracy $R P w$ obliczu przemian, Warszawa.

Kryńska E. (2006), Wydtużanie życia zawodowego na polskim rynku pracy, „Polityka Społeczna” nr 9, s. $1-6$.

Lipka A. (2002), Ryzyko personalne. Szanse i zagrożenia zarządzania zasobami ludzkimi, Warszawa.

Ministerstwo Pracy i Polityki Społecznej (2014a), Pomoc urzędu pracy w zatrudnianiu młodych bezrobotnych - instrumenty wprowadzone w $2014 \mathrm{r}$., Warszawa.

Ministerstwo Pracy i Polityki Społecznej (2014b), Dodatkowe instrumenty adresowane do bezrobotnych do 30 roku życia - kierunkowe wytyczne dla powiatowych urzędów pracy, Warszawa.

Ministerstwo Rodziny, Pracy i Polityki Społecznej (2016), Analiza rozwiazań wprowadzonych ustawa z dnia 14 marca 2014 r. o zmianie ustawy o promocji zatrudnienia i instytucjach rynku pracy oraz niektórych innych ustaw Dz.U., poz. 598, Warszawa.

Rotkiewicz M. (2015), Dodatkowe instrumenty adresowane do bezrobotnych do 30. roku życia, [w:] M. Culepa, M. Rotkiewicz, D. Wołoszyn-Kądziołka, Ustawa o promocji zatrudnienia $i$ instytucjach rynku pracy. Komentarz, Warszawa.

Skąpski M. (2006), Ochronna funkcja prawa pracy w gospodarce rynkowej, Kraków.

Staszewska E. (2010), Pojęcie „osób będacych w szczególnej sytuacji na rynku pracy” w świetle ustawy o promocji zatrudnienia i instytucjach rynku pracy, "Zeszyty Prawnicze UKSW” nr 10.1, s. 233-246.

Staszewska E. (2012), Środki prawne przeciwdziałania bezrobociu, Warszawa.

Staszewska E. (2013), Staż dla bezrobotnych - instrument aktywizacji zawodowej osób będacych w szczególnej sytuacji na rynku pracy, [w:] Z. Góral (red.), Bezrobocie i polityka zatrudnienia, Warszawa.

Suknarowska-Drzewiecka E. (2010), Staż, „Monitor Prawa Pracy”, nr 8, s. 415-418.

Szylko-Skoczny M. (2004), Polityka społeczna wobec bezrobocia w Trzeciej Rzeczypospolitej, Warszawa. 
Tomaszewski A. (2011), Problem dostosowania oferty szkolnictwa wyższego do potrzeb rynku pracy, [w:] A. Rogozińska-Pawełczyk, D. Majewski (red.), Absolwent na rynku pracy, Łódź.

Urbaniak B. (2007), Trudności pracowników w wieku 45+ i ich problemy, „Polityka Społeczna” nr 1, s. 10-14.

Ustawa o zatrudnieniu z dnia 29 grudnia 1989 r., (Dz.U. nr 75, poz. 446 ze zm.).

Ustawa o zatrudnieniu i bezrobociu z dnia 16 października 1991 r., (Dz.U. nr 106, poz. 457 ze zm.).

Ustawa o zatrudnieniu i przeciwdziałaniu bezrobociu z dnia 14 grudnia 1994 r. (Tekst jedn. Dz.U. z 2001 r., nr 6, poz. 56 ze zm.).

Ustawa o świadczeniu usług drogą elektroniczną z dnia 18 lipca 2002 r. (Tekst jedn. Dz.U. z 2013 r., poz. 1322).

Ustawa o promocji zatrudnienia i instytucjach rynku pracy z dnia 20 kwietnia 2004 r. (Tekst jedn. Dz.U. z 2016 r., poz. 645 ze zm.).

Ustawa o zmianie ustawy o promocji zatrudnienia i instytucjach rynku pracy oraz niektórych innych ustaw z dnia 14 marca 2014 r. (Dz.U. z 2014 r., poz. 598).

\title{
Ewa Staszewska
}

\section{NEW LABOUR MARKET INSTRUMENTS AIMING TO ACTIVATE DISADVANTAGED GROUPS IN THE LABOUR MARKET IN THE LIGHT OF THE ACT ON EMPLOYMENT PROMOTION AND LABOUR MARKET INSTITUTIONS}

\begin{abstract}
The subject matter of the article are labour market instruments aiming at professional activation of disadvantaged groups in the labour market. The analysis focused on new labour market instruments which are included to the Act of 2004 on employment promotion and labour market institutions, after latest extensive amendment made on May, 2014. New labour market instruments are intended to increase job centres' flexibility by better adjusting their services to the needs of the given unemployed and employer. The fundamental purpose of the new labour market instruments is to help young people (up to 30 years of age) and older unemployeds (over 50) enter and stay on the labour market, as well as take measures to facilitate the balance between work and family life. For young unemployed under 30 the new labour market instruments were introduced with a view to motivating them to take up individual job seeking activities (e.g. implemented system of vouchers). In order to activate professionally the $50+$ unemployeds, the possibility of obtaining co-funding compensations for employers who employ jobless in this age group has been established. Also, new instruments for unemployed who want to hold balance between work and family life have been introduced - grant for teleworking, job seeking allowances.

Keywords: disadvantaged groups in the labour market; labour market instruments; a system of vouchers; grant for teleworking; subsidized employment
\end{abstract}

JEL: E24, I38, J14, J21, J23, J24, J29, J61, J64, J68, J69, K31 